\title{
The Effect Of CAR, NPL \& LDR On The Profit Improvement Of Regional Development Bank In Indonesia By Using Credit Growth As Intervening Variable (Research on Regional Development Banks in Java, Bali \& NTT) Period 2011 - 2015
}

\author{
Ririn Poerwanti, Titis Puspitaningrum Dewi Kartika \\ STIE Perbanas, Surabaya \\ Email : ririn@perbanas.ac.id, titis_puspita@perbanas.ac.id
}

\begin{tabular}{|c||c||c|}
\hline Accepted : & Reviewed : & Published : \\
November, 03 2017 & January, 03 2018 & March, 30 2018 \\
\hline
\end{tabular}

\begin{abstract}
Purpose: This study aimed to analyze the effect of CAR, NPL, and LDR on credit growth in the 8 (eight) Regional Development Bank in Indonesia, especially in Java, Bali \& NTT in the period 2011-2015.

Design/methodology/approach: The samples used were taken using census method which includes the entire population..

Findings: Partial test result indicate that CAR is negative and significant effect on credit growth as well as a significantly positive effect on earning growth. NPL ratio partially no significant effect on credit growth but significant effect on earning growth.

Research limitations/implications: LDR no significant effect on credit growth but significantly and positively affect profit growth while existing credit growth is able to mediate the perpetually perfect (perfect mediation) between CAR, NPL and LDR on regional development bank profit growth in Java, Bali and NTT in the period 2011 to 2015.

Practical implications: 2. The financial ratios assessed from the CAR, NPL and LDR before involving intervening variables of credit growth significantly affected the increase in profit at Regional Development Banks in Java, Bali and NTT as evidenced by simultaneous test results with P-value of F or significance of 0.019 <a '(5\%).

Originality/value: The ratio of CAR, NPL and LDR significantly affects credit growth in Regional Development Banks in Java, Bali and NTT through simultaneous testing with P value of F or a significance level of $0.004<a$ '(5\%).

Paper type: Research paper
\end{abstract}

Keyword: Internal Quality Assurance System, Information Technology, Integrated System and Competitive Advantage

Keywords : CAR, NPL, LDR, Credit Growth and Profit Growth

\section{INTRODUCTION}

Bank is the most important financial institution and greatly affect the economy either micro or macro. As we know, banks have a large market share of the entire existing financial system. Given the enormous role of banks in Indonesia, decision makers need to evaluate adequate performance.Banking institutions is one of the

The Effect Of CAR, NPL \& LDR On The Profit Improvement Of Regional Development Bank In Indonesia By Using Credit Growth As Intervening Variable (Research on Regional Development Banks in Java, Bali \& NTT) Period $2011-2015$

Ririn Poerwanti, Titis Puspitaningrum Dewi Kartika 
foundation of a country's economy, because it has an intermediary function or as an intermediary between the fund supplier and the fund user.

The role of Regional Development Bank as one of the spearheads of regional development, especially in the real sector is now increasingly important, in line with the existence of regional autonomy. One such effort is to maximally provide the need for funds to be lent to the public as business capital (productive credit) or the availability of funds for consumption for public (consumer credit).

On the other hand, credit is one of the main activities of Regional Development Banks in addition to collect funds from public. This is in line with the main purpose of the establishment of a bank that is as a financial intermediary between party who distributes fund with party who needs fund, and seek profit from operational activities. It shows us that credit is able to mediate between the functions of the bank through its operational activities and the purpose of bank establishment through the growth of profit.

Some of currently important issues at Regional Development Bank in Java, Bali \& NTT are the decline in the number of lending, particularly in credit consumption, which is allegedly owing to the low returning rate of debtors. As the result, Regional Development Bank in Java, Bali \& NTT limited on disbursing funds (Indonesian Finance Today, 2013). Credit growth of Regional Development Banks in Java, Bali \& NTT can be seen in table 1 below.

Table 1: Credit Growth of Regional Development Banks in Java, Bali \& NTT in 2011 - 2015

\begin{tabular}{|c|c|c|c|c|c|c|}
\hline No & Bank BPD & 2011 & 2012 & 2013 & 2014 & 2015 \\
\hline 1 & Bank DKI & $24.21 \%$ & $36.74 \%$ & $33.78 \%$ & $21.82 \%$ & $14.39 \%$ \\
\hline 2 & Bank Jatim. & $24.23 \%$ & $14.13 \%$ & $17.80 \%$ & $18.18 \%$ & $7.35 \%$ \\
\hline 3 & Bank Jateng & $14.32 \%$ & $34.48 \%$ & $18.53 \%$ & $18.86 \%$ & $17.21 \%$ \\
\hline 4 & Bank Jabat / Banten & $22.35 \%$ & $30.49 \%$ & $28.08 \%$ & $9.44 \%$ & $5.75 \%$ \\
\hline 5 & Bank Jogjakarta & $19.60 \%$ & $18.09 \%$ & $21.33 \%$ & $34.10 \%$ & $11.93 \%$ \\
\hline 6 & Bank Bali & $16.16 \%$ & $17.21 \%$ & $-88.17 \%$ & $23.68 \%$ & $15.24 \%$ \\
\hline 7 & Bank Nusa Tenggara Timus & $32.46 \%$ & $15.23 \%$ & $11.26 \%$ & $13.66 \%$ & $17.63 \%$ \\
\hline 8 & Bank Nusa Tenggara Barat & $29.46 \%$ & $13.35 \%$ & $8.43 \%$ & $23.62 \%$ & $12.52 \%$ \\
\hline & Rata-rata & $182.79 \%$ & $179.72 \%$ & $51.04 \%$ & $163.36 \%$ & $102.02 \%$ \\
\hline
\end{tabular}

Source: Publication Report of Indonesian Banks 2016

The declining rate of credit growth that reached the lowest average level in 2013 indicates an effort to lending restrain by Regional Development Banks in Java, Bali \& NTT. It is also felt for small and medium credit business that it is difficult to obtain information of funding loans and the limited information for public. The role of Regional Development Bank as a financial intermediary or the party who has excess funds with the party who needs funds. This is also in line with the purpose of Regional Development Bank establishment, which seeks profit through the interest of loan. Nevertheless, the contribution of credit growth provided by Regional Development Banks on the increase of profit will be felt if the Regional Development Bank is able to seek adequate capital

The Effect Of CAR, NPL \& LDR On The Profit Improvement Of Regional Development Bank In Indonesia By Using Credit Growth As Intervening Variable (Research on Regional Development Banks in Java, Bali \& NTT) Period $2011-2015$

Ririn Poerwanti, Titis Puspitaningrum Dewi Kartika 
availability as well, so that the financial performance of banks seen from the financial statements of banks will be decisive, because the assessment of financial performance of banks is necessary to interpret the financial condition that is happening to the bank. As a result, Bank's operational activities in providing loans can be increased and profits could be obtained.

\section{MATERIAL AND METHOD}

\section{Previous Research}

1. Dwi Lestari (2012) examined the Bank's Financial Ratios to the profit growth in Foreign Exchange Banks listed on the Stock Exchange. The results showed that CAR variables have a significant positive effect on ROA. This proved that the capital adequacy in doing their business had to be fulfilled. LDR had a significant positive effect on ROA, and $\mathrm{F}$ test showed that CAR and LDR variables have significant effect on ROA. The research obtained the coefficient of determination (R2) $23,6 \%$.

2. Eddy Herjanto (2012) examined the factors that affect the profitability of banks. The results of this research showed that CAR \& LDR variables have a positive effect but not significant on ROA while NPL variables have a negative effect and insignificant on ROA. Some researchers such as Werdaningtyas (2002), Suryono (2007), and Rinawan (2009), showed that Capital Adequacy Ratio (CAR) has a positive and significant effect on Return On Assets (ROA). It is different with the research conducted by Sarifudin (2005) which showed that Capital Adequacy Ratio (CAR) has a negative effect and insignificant on Return On Assets (ROA).

3. Sianturi research (2012) showed that CAR and LDR variables had positive but not significant effect on ROA, and NPL variable had negative effect and insignificant on ROA, while BOPO variable had negative effect and significant on ROA and NIM variable had positive effect and significant to ROA. The prediction ability of the five independent variables to ROA is equal to $73.6 \%$ which is directed from the adjusted R2, the remaining $26.4 \%$ is explained by other variables beyond the research model.

4. From the result of the research conducted by Pelo (2012), found that CAR and NPL have negative effect and insignificant on ROA. While BOPO, LDR and NIM have positive effect and significant on ROA. In addition, this study also proved that CAR, NPL, BOPO, LDR and NIM simultaneously influence the ROA of government banks.

5. Mawardi research (2005) found that NPL and BOPO have significant negative effect. While the NIM has a significant positive effect. The CAR ratio has no significant effect. The dependent variable in this research is banking profitability performance (ROA). Research conducted by Yuliani (2007) showed that CAR has significant effect on ROA, while LDR has no significant effect on ROA.

6. Renaldy, Andreas \& Errin (2014) conducted a research which proved that LDR has no significant effect on credit growth, but significantly and positively affects the profit growth. On the other hand, credit

The Effect Of CAR, NPL \& LDR On The Profit Improvement Of Regional Development Bank In Indonesia By Using Credit Growth As Intervening Variable (Research on Regional Development Banks in Java, Bali \& NTT) Period $2011-2015$

Ririn Poerwanti, Titis Puspitaningrum Dewi Kartika 
growth here could perfectly mediate between financial ratios consisting of CAR, NPL, NIM, ROA and LDR against bank's profit growth.

7. Sustari Alamsyah (2015) research result showed that the variables of Capital Adequacy Ratio (CAR) and Loan to Deposit Ratio (LDR) affect earnings growth. While the variable Non Performing Loan (NPL), Return On Asset (ROA) \& Net Interest Margin (NIM) has no effect on profit growth.

8. Noni Nuraini (2016) proved in her research that it was partially obtained that the change of ROA \& NPM have positive effect \& significant to the profit change, while BOPO variable have positive effect and insignificant, LDR variable has negative effect and insignificant to the profit change.

9. Kumbirai Mabwe (2010), A Financial Ratio Analysis of Commercial Bank Performance in South Africa, Journal for Economic \& Finance. This resulted in falling profitability, low liquidity and deteriorating credit quality in the South African Banking sector

10. Rini D.H (2016), The Influence of the Bank's Performance Ratio to Profit Growth on Banking Companies in Indonesia. This result of this study shows that independent variables including, Capital, Asset, Earning, \& Liquidity Ratio have significant \& simultaneous influence toward the dependent variable, which is Profit Growth. Liquidity Ratio only has partially significant positive influence on Profit Growth.

11. Ida Bagus SP, Anik Y \& Putu K, (2018), "The Influence of Internal and External Factors with Risk Factors as Mediation Variable to Financial Performance of Regional Development Bank in Indonesia". The result of the research shows that the internal factor of the bank has a significant positive effect on the financial performance; the internal factor of the bank has a significant negative effect on the risk factor; the external factor on the bank has a significant negative effect on financial performance; the external factor of the bank has a significant positive effect on the risk factor; the risk factor have a significant negative effect on financial performance; the internal factor of bank significantly have positive effect to financial performance which is mediated by bank risk factor; the external factor of bank significantly negatively affect to financial performance. Indicators internal factor variables are asset growth, credit growth \& fund growth. External factor variable indicator is inflation, BI rate \& exchange rate. Indicator for risk factor variable are NPL, LDR, BOPO, CAR. Indicator of financial performance variables are ROA, ROE, \& NIM

\section{LITERATUR REVIEW}

Bank capital theory does provide guidance in bank management decision-making. But, still, the bank as a financial institution that is obey the regulation must still pay attention to capital adequacy in regulator perspective. Conceptually, for instance, the owners of over-capitalized banks are considered inefficient, yet large capital will lead banks to act more prudently in managing them. Meanwhile, if capital is too small, it will reduce the public mistrust to the bank. Capital Adequacy Ratio (CAR), is a ratio to measure the capital adequacy of a

\footnotetext{
The Effect Of CAR, NPL \& LDR On The Profit Improvement Of Regional Development Bank In Indonesia By Using Credit Growth As Intervening Variable (Research on Regional Development Banks in Java, Bali \& NTT) Period $2011-2015$
}

Ririn Poerwanti, Titis Puspitaningrum Dewi Kartika 
bank to support assets that consist or generate risks, such as loans. Banks including safe banks, if they have at least $8 \%$ of CAR.

Non-Performing Loan (NPL) is a financial ratio used to view credit repayment rates given by depositors to banks. In other word, Non-Performing Loan (NPL) represents the level of bad debts of the bank. The lower Non-Performing Loan (NPL), the more profit would be obtained by the bank. Meanwhile, the higher NonPerforming Loan (NPL), the less profit of Bank would gain as the result of bad credit repayment rate.

Liquidity Ratio or Loan to Deposit Ratio (LDR) is the ratio between Total Credits provided with Total Third Party Funds (DPK) that are collected by the bank. Liquidity Ratio (LDR) shows the level of bank's ability in distributing third parties' funds collected by the bank concerned. In other words, Loan to Deposit Ratio is the ratio of bank performance to measure bank liquidity in fulfilling the needs of funds drawn by the public in the form of savings, demand deposits and time deposits.

Nonetheless, in reality, not all financial ratios of CAR, NPL \& LDR are directly proportional to credit growth and profit improvement. This can be seen from the increase of Regional Development Banks' profit in Java, Bali \& NTT in 2011 to 2015 as follows:

Table 2: Profit Increasing of Regional Development Banks in Java, Bali \& NTT 2011 - 2015

\begin{tabular}{|c|c|c|c|c|c|c|}
\hline No & Bank BPD & 2011 & 2012 & 2013 & 2014 & 2015 \\
\hline 1 & Bank DKI & $71.02 \%$ & $12.62 \%$ & $74.63 \%$ & $-21.45 \%$ & $-36.61 \%$ \\
\hline 2 & Bank Jatim & $1.17 \%$ & $-14.65 \%$ & $13.81 \%$ & $13.05 \%$ & $5.85 \%$ \\
\hline 3 & Bank Jateng & $7.32 \%$ & $37.07 \%$ & $25.44 \%$ & $3.26 \%$ & $11.95 \%$ \\
\hline 4 & Bank Jabat / Banten & $6.40 \%$ & $25.13 \%$ & $16.10 \%$ & $-19.70 \%$ & $4.22 \%$ \\
\hline 5 & Bank Jogjakarta & $20.54 \%$ & $15.90 \%$ & $24.27 \%$ & $21.87 \%$ & $19.23 \%$ \\
\hline 6 & Bank Bali & $80.00 \%$ & $44.81 \%$ & $6.13 \%$ & $12.53 \%$ & $1.92 \%$ \\
\hline 7 & Bank Nusa Tenggara Timus. & $23.52 \%$ & $14.88 \%$ & $20.20 \%$ & $7.32 \%$ & $-10.84 \%$ \\
\hline 8 & Bank Nusa Tenggara Barat & $14.63 \%$ & $20.56 \%$ & $-3.50 \%$ & $17.57 \%$ & $15.97 \%$ \\
\hline & Average & $224.60 \%$ & $156.32 \%$ & $177.08 \%$ & $34.45 \%$ & $11.69 \%$ \\
\hline
\end{tabular}

Source: Publication Report of Indonesian Banks 2016

The average fluctuation of the unstable profit increase indicates the ineffectiveness of the bank in carrying out its goal of earning profit with positive trend every year. The purpose of this research is to see the relationship of financial ratios consisting of CAR, NPL \& LDR on credit growth and profit improvement in Regional Development Bank in Java, Bali \& NTT and to know the influence of credit growth to the increasing of Regional Development Bank's profit in Java, Bali \& NTT.

The Effect Of CAR, NPL \& LDR On The Profit Improvement Of Regional Development Bank In Indonesia By Using Credit Growth As Intervening Variable (Research on Regional Development Banks in Java, Bali \& NTT) Period $2011-2015$

Ririn Poerwanti, Titis Puspitaningrum Dewi Kartika 
Several previous studies have observed the effects of financial ratios (CAR, BOPO, NIM, NPL and LDR) on credit growth and profit growth in various banks both in Indonesia and abroad, among others are research conducted by Aini (2006), Yunianingsih 2011), Prayudi (2011), Rahman (2009) and Prastiono (2009).

\section{Theoretical Framework}

Credit is one of the main activities of the Regional Development Bank in addition to collecting funds from the public. This is in line with the main objective of bank establishment that is as a financial intermediary between parties who distributes funds with parties who need funds, and seek profit from the operational activities. This shows us that credit is able to mediate between the functions of the bank through its operational activities and the purpose of bank establishment through an increase in profit. The conceptual framework of the study can be described as shown in Figure 1 as follows:

Figure 1. : Conceptual Framework of Research

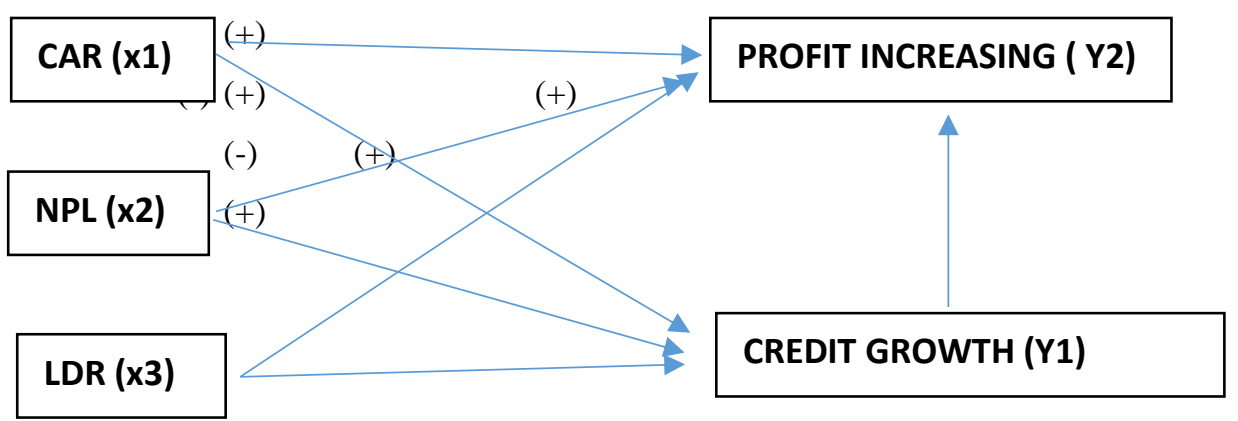

Source : Riyadi,2006;Renaldy, 2009; Dendawidjaya, 2009; Limpaphayom and Polwitoon, 2004

\section{RESULT AND DISCUSSION}

\section{The Result of Descriptive Data Analysis}

Credit growth in Regional Development Banks in Java, Bali \& NTT during the period of research (20112015) experienced a growth of $135.78 \%$ with the highest credit growth achieved by PT. Bank DKI in the year 2012 amounted to 36.74\% and decrease the amount of the lowest credit obtained by PT. Bank Bali in 2013 ($88.17 \%)$.

The significant increase of profit by PT Bank Bali in 2011 was 80\%, while profit decrease faced by PT. Bank DKI -36.61\% in 2015. Increasing the number of customers at PT. Bank Bali is believed to be involved in increasing the amount of funds deposited in the bank, so that Bank Bali can perform financial activities with the maximum level of profit. While at Bank DKI, fluctuating regional economic condition has not been stable because post reformation affected banking activities, so the bank is difficult to maximize its performance.

Capital Adequacy Ratio (CAR) ratio is the capital adequacy ratio owned by banks to support assets that consist or generate risk. The maximum CAR ratio of PT. Bank NTB in 2015 with a percentage of $27.59 \%$, while the lowest CAR ratio of PT. Bank DKI amounted to $9.57 \%$ in 2011. The average performance of capital adequacy ratio at Regional Development Bank in Java, Bali and NTT is 138.78\%

The Effect Of CAR, NPL \& LDR On The Profit Improvement Of Regional Development Bank In Indonesia By Using Credit Growth As Intervening Variable (Research on Regional Development Banks in Java, Bali \& NTT) Period $2011-2015$

Ririn Poerwanti, Titis Puspitaningrum Dewi Kartika 
The NPL ratio is the ratio used to measure the ability of bank management to manage the problem loans provided by the bank. Based on descriptive analysis, the performance of NPL ratio shown by PT. Bank DKI was $4.23 \%$ in 2015, while the performance of the lowest NPL ratio in the of PT. Bank Bali was $0.10 \%$ in 2014. The average NPL performance shown by Regional Development Banks in Java, Bali and NTT while the study conducted was $6.34 \%$.

Furthermore, the financial performance of Regional Development Banks in Java, Bali and NTT measured through the growth of Loan to Deposit Ratio (LDR) is the ratio between total loans provided with total third parties' funds (DPK). This ratio will show the level of banks' ability in channeling third parties' funds collected by the bank concerned. Based on the results of descriptive research, the performance of the maximum LDR ratio shown by PT. Bank NTB in 2012 amounted to $108.41 \%$, while the performance of the lowest LDR ratio exposed by PT. Bank DKI in 2011 is $23.03 \%$.

\section{Data Normality}

Prior to testing by using regression method using intervening variable, the data requirement that is feasible to be tested is that data must be in normal distribution. Then, based on the outliers' test results, obtained as many as 5 (five) observations that are classified as outliers must be removed from the observation, so that the writer obtained as many as 25 observations which are free from outliers. Normality test is used to test whether in a regression model, variable dependent, independent variable, or both of them have normal distribution or not. A good regression model is a normal or near-normal distribution (Santoso, 2002; 212). The graph of data normality distribution can be shown through figure 2 as follows:

\section{Figure 2: Normal Graph P-P Plot of Regression Standardized Residual}

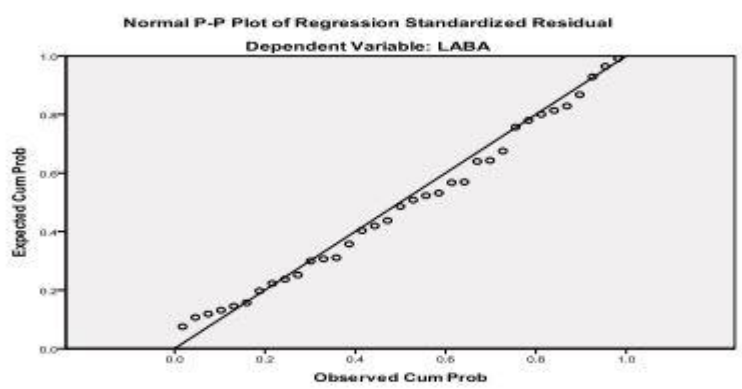

Based on Figure 2, it can be concluded that the data spread around the normal line and follow the direction of the diagonal line of regression. This figure shows that the regression model has met the assumption of normality.

Tests based on the value of Kosmolgorov-Siirnov can be seen in table 3 as follows:

Table 3: Calculation result of Non-Parametric Test One-Sample Kolmogorov-Smirnov Test

\begin{tabular}{|lr|l|l|l|l|l|}
\hline & & CAR & NPL & LDR & KREDIT & LABA \\
\hline $\mathrm{N}$ & & 25 & 25 & 25 & 25 & 25 \\
Normal & Mean & 20.0446 & 2.5749 & 88.3077 & 26.786 & 28.532 \\
Parameters & Std & 7.66454 & 1.25416 & 9.558 & 17.78345 & 4.81447
\end{tabular}

The Effect Of CAR, NPL \& LDR On The Profit Improvement Of Regional Development Bank In Indonesia By Using Credit Growth As Intervening Variable (Research on Regional Development Banks in Java, Bali \& NTT) Period $2011-2015$

Ririn Poerwanti, Titis Puspitaningrum Dewi Kartika 


\begin{tabular}{|c|c|c|c|c|c|c|}
\hline \multirow{2}{*}{\multicolumn{2}{|c|}{$\begin{array}{ll} & \text { Deviation } \\
\text { Most } & \text { Absolute }\end{array}$}} & \multirow[b]{2}{*}{0.156} & \multirow[b]{2}{*}{0.171} & \multirow[b]{2}{*}{0.232} & \multirow[b]{2}{*}{0.087} & \multirow[b]{2}{*}{0.15} \\
\hline & & & & & & \\
\hline Extreme & Positive & 0.156 & 0.171 & 0.102 & 0.087 & 0.15 \\
\hline Differences & Negative & -0.101 & -0.109 & -0.232 & -0.057 & -0.089 \\
\hline $\begin{array}{l}\text { Kolmogorov - } \\
\text { Z }\end{array}$ & Smirnov & 0.921 & 1.01 & 1.375 & 0.513 & 0.889 \\
\hline \multicolumn{2}{|c|}{ Asymp. Sig. (2-tailed) } & 0.364 & 0.26 & 0.046 & 0.955 & 0.408 \\
\hline
\end{tabular}

a. Test distribution is Normal.

b. Calculated from data

Source: Research of Data Processed, 2013

The test by using Kolmogorov-Smirnov One-Sample Test method is done by looking at Asymp.Sig value. (2-tailed) with normality testing criteria with Asymp value. Sig. (2-tailed) greater than 0.05 . Then the data is normally distributed (Wijaya: 2008).

\section{Classical Assumption Testing}

In multiple regression analysis, it is necessary to avoid any deviation of classical assumption to avoid problems in the use of multiple regression analysis (Gujarati, 2002). There are three classical assumption test; they are Multicolinearity test, Autocorrelation test, and Heteroskedasticity test.

\section{Multicollinearity Test}

The tests performed on the first three classical assumptions are the tests of multicolinearity. The multicollinearity test is done to test whether there is perfect relationship between independent variable and dependent variable on the regression model (Santoso, 2002: 206-207). In other words, this test is done not because the presence of multicolinearity but whether it is dangerous or not, since there is no similarity without multicoleniarity. The rule of thumb used to determine that the Tolerance value is not harmful to the symptoms of multicolinearity which is 0.1 . The results of multicolinearity testing for this study data can be explained by using coefficient table by paying attention to collinearity diagnostic column as table 4 below:

Table 4: Testing result of Multicolinearity using Coefficient Collinearity Statistic table

\begin{tabular}{|c|c|}
\hline \multicolumn{2}{|c|}{ Collinearity Statistics } \\
\hline Tolerance & VIF \\
.885 & 1.130 \\
.754 & 1.326 \\
.905 & 1.105 \\
.808 & 1.238 \\
.913 & 1.095 \\
.786 & 1.273 \\
\hline
\end{tabular}

Based on the test of multicolinearity assumption on observation that has been done, then obtained the test results can be seen in table 4 and it can be concluded that based on the Tolerance value independent variables show a value more than 0.1 , and based on its VIF value less than 10 thus all independent variables are free from testing classical assumptions.

The Effect Of CAR, NPL \& LDR On The Profit Improvement Of Regional Development Bank In Indonesia By Using Credit Growth As Intervening Variable (Research on Regional Development Banks in Java, Bali \& NTT) Period $2011-2015$

Ririn Poerwanti, Titis Puspitaningrum Dewi Kartika 


\section{Autocorrelation Test}

If the value of Durbin Watson Statistic approaching 2 (two), it indicates that there is no autocorrelation. Another way used to detect symptoms of autocorrelation can use rule of thumb, if the value of $d u<d<4-d u$ then there is no autocorrelation (Gujarati, 2002).

Table 5: Summary Model

\begin{tabular}{|c|c|c|c|c|c|}
\hline Model & $\mathrm{R}$ & R Square & Adjusted R Square & $\begin{array}{l}\text { Std. Error of the } \\
\text { Estimate }\end{array}$ & Durbin-Watson \\
\hline 1 & $.752^{\mathrm{a}}$ & 566 & .473 & 3.49501 & 1.851 \\
\hline
\end{tabular}

a. Predictors: (Constant), CREDIT, CAR, LDR, NPL

b. Dependent Variable: PROFIT

Source: Research of Data Processed, 2018

Based on Durbin-Watson table, for the number 25 observations and k equal to 4 , then obtained the value $\mathrm{dl}$ equal to the value $\mathrm{dl}$ of 1.4443 with du 1.851. Therefore, the rule of thumb in autocorrelation testing as follows $1.097<1.884<4-1.884$ or $1.097<1.884>1.851<2.116$

Based on the Durbin Watson equation, it cannot be concluded whether or not there is autocorrelation. This is supported by D-W calculation criterion which shows that D-W value is between -2 and +2 , so it can be stated that the tested data is free from autocorrelation, so it does not need to be removed from the regression model.

\section{Heteroskidity Test}

This test is conducted in order to see the squared distance of the distribution points to the regression line. To detect this can be done with various ways. In this study to detect the presence of heteroskidity symptoms done by Scatter Plot method.

Figure 3 : Scatter Plot

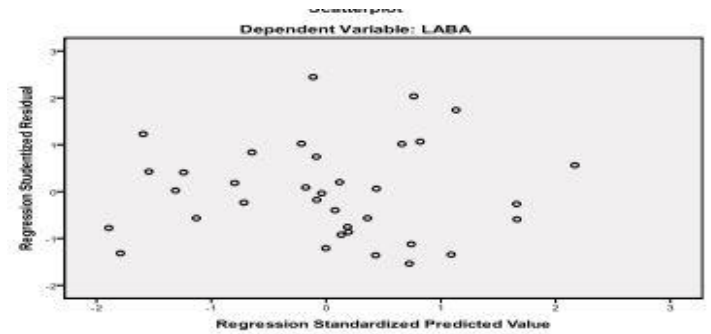

Based on the calculation results, there was obtained in the form of Scatter-Plot, which there is no clear pattern as well as the spreading points. Therefore, all of the free independent variables from the third classical assumption testing do not need to be removed from regression model.

\section{Regression Analysis}

Statistical analysis used in this study Multiple Linier Regression by using intervening variable (mediation). As its principle, regression analysis using this method requires three stages (Suliyanto, 2011):

The Effect Of CAR, NPL \& LDR On The Profit Improvement Of Regional Development Bank In Indonesia By Using Credit Growth As Intervening Variable (Research on Regional Development Banks in Java, Bali \& NTT) Period $2011-2015$

Ririn Poerwanti, Titis Puspitaningrum Dewi Kartika 
1. Regression Analysis I Equation (Intervening Variable as Dependent Variable)

2. Regression Analysis II (Without Intervening Variable as Independent Variable)

3. Regression Analysis by involving Intervening Variables in equation II

4. Comparing regression coefficient of each free variable before and after entering intervening variables, and by removing Intervening variable with criteria as follows:

a. Variable YI (Intervening Variable) is stated as a perfect mediation variable if, after entering variable YI, the effect of variable $\mathrm{X}$ to $\mathrm{Y} 2$ decreases to zero (coefficient $=0$ ) or the effect of variable $\mathrm{X}$ to $\mathrm{Y} 2$ which was significant (before entering YI variable) becoming insignificant after entering the YI variable into the regression equation model.

b. The variable YI is stated as a partial mediation variable if, after entering the variable YI the effect of variable X to Y2 decreases but not to zero (coefficient " d 0) or the effect of variable X to Y2 which was significant (before entering variable YI) still becoming significant after entering the YI variable into the regression equation model, but decreased in regression coefficient.

\section{Research Hypothesis Testing}

Based on test results using multiple linear regression method, it can be analyzed the effects of CAR, NPL and LDR ratios to increase profit with credit growth as intervening variable at Regional Development Bank in Java, Bali and NTT in 2011 - 2015.

\section{Capital Adequacy Ratio (CAR) Effect on Credit Growth}

Ho1. CAR ratio has no positive and significant impact on credit growth in Regional Development Banks in Java, Bali and NTT.

Ha1. CAR ratio has a positive and significant effect on credit growth in Regional Development Banks in Java, Bali and NTT.

Based on the test results on CAR on credit growth, it showed that CAR ratio negatively affected by -0.856 and significant to credit growth with a significance level of 0.019 ( $\mathrm{p}<0.05)$. Hence, it can be concluded that the hypothesis (Ha1) which states that the CAR Ratio has a positive and significant effect on credit growth in Regional Development Banks in Java, Bali and NTT is unacceptable.

\section{Non-Performing Loan (NPL) Effect on Credit Growth}

Ho2. NPL ratio has no negative and significant effect on credit growth in Regional Development Banks in Java, Bali and NTT

Ha2. The NPL ratio has negative and significant effect on credit growth in Regional Development Banks in Java, Bali and NTT

\footnotetext{
The Effect Of CAR, NPL \& LDR On The Profit Improvement Of Regional Development Bank In Indonesia By Using Credit Growth As Intervening Variable (Research on Regional Development Banks in Java, Bali \& NTT) Period $2011-2015$
}

Ririn Poerwanti, Titis Puspitaningrum Dewi Kartika 
Based on the test results in equation I, it was obtained a significant value for NPL ratio variable on credit growth of 0.092 ( $>0.05$ ) and on regression coefficient of -3.798 . Hence the hypothesis (Ha2) which states that the NPL ratio has a negative and significant effect on credit growth in Regional Development Banks in Java, Bali and NTT.

\section{Loan to Depost Ratio (LDR) Effect on Credit Growth}

Ho3. LDR ratio has no significant and positive effect on credit growth in Regional Development Banks in Java, Bali and NTT

Ha3. LDR ratio has positive and significant impact on credit growth in Regional Development Banks in Java, Bali and NTT.

The results showed that Loan to Deposit Ratio (LDR) ratio did not significantly influenced on credit growth with a significance value of 0.378 ( $p>0.05$ ) with a regression coefficient of 0.249 . Hence, based on the results of the study, it can be concluded that the hypothesis (Ha3) which states that the LDR ratio has positive and significant effect on credit growth in Regional Development Banks in Java, Bali and NTT cannot be accepted.

\section{Capital Adequacy Ratio (CAR) Effect on Profit Improvement}

Ho 4. The CAR ratio has no positive and significant effect on profit improvement in Regional Development Banks in Java, Bali and NTT.

Ha 4. CAR Ratio has positive and significant effect on profit improvement in Regional Development Banks in Java, Bali and NTT.

Based on the test results, it was obtained significant value of CAR variable to profit improvement of 0.001 ( $p<0.05$ ) with the value of regression coefficient of 0.227 which showed that CAR significantly has positive effect on profit improvement. Based on the test result, it can be concluded that the hypothesis (Ha4) which states that the CAR ratio has positive and significant effect to profit improvement on Regional Development Banks in Java, Bali and NTT is acceptable.

\section{Non-Performing Loan (NPL) Effect on Profit Improvement}

Ho 5. NPL ratio has no negative and significant effect to the profit improvement in Regional Development Banks in Java, Bali and NTT.

Ha 5. The NPL ratio has negative and significant effect to the profit improvement in Regional Development Banks in Java, Bali and NTT.

Based on regression test results, it was obtained significant value of NPL variable to profit improvement of $0.002(\mathrm{p}<0.05)$ and regression coefficient of -1.291 which indicates that NPL has negative and significant effect to profit improvement. Based on the test results on equation II, it can be concluded

\footnotetext{
The Effect Of CAR, NPL \& LDR On The Profit Improvement Of Regional Development Bank In Indonesia By Using Credit Growth As Intervening Variable (Research on Regional Development Banks in Java, Bali \& NTT) Period $2011-2015$
}

Ririn Poerwanti, Titis Puspitaningrum Dewi Kartika 
that the hypothesis (Ha5) which states NPL ratio has negative and significant effect on profit improvement in the Regional Development Banks in Java, Bali and NTT is acceptable.

\section{Loan to Deposit Ratio (LDR) Effect on Profit Improvement}

Ho 6. The LDR ratio has no positive effect to profit improvement in Regional Development Banks in Java, Bali and NTT.

Ha 6. The LDR ratio has positive effect to profit improvement in the Regional Development Banks in Java, Bali and NTT.

Based on the test results, it was obtained LDR variable significance to the increase on profit improvement 0.017 ( $\mathrm{p}<0.05)$ with regression coefficient value of 0.131 which indicates that LDR significantly and positively affect profit improvement. Based on the test result on equation II, it can be concluded that the hypothesis (Ha6) which states that the LDR ratio has a positive and significant effect on the increase of profit in Regional Development Banks in Java, Bali and NTT is acceptable.

\section{The Effect of Credit Growth on Profit Improvement}

Ho 7. Credit growth cannot mediate positively on the effects of CAR, NPL and LDR ratios on the profit improvement of the Regional Development Bank in Java, Bali and NTT.

Ha 7. Credit growth can mediate positively on the effects of CAR, NPL and LDR ratios on the profit improvement of the Regional Development Bank in Java, Bali and NTT.

Based on the test results, it was obtained the comparison of coefficient value of free variable regression before and after involving profit improvement intervening variable. Based on the test criteria on intervening variable that is if the variable is included into the second equation, then there is a change of free variable coefficient value which then becomes not entirely significant. Therefore, that intervening variable can be the mediator of the independent variable relationship to bound variable perfectly (perfect mediation). Hence, it can be concluded that hypothesis (Ha 7) which states that credit growth is able to mediate positively on the effects caused by CAR, NPL and LDR ratio to profit improvement of Regional Development Banks in Java, Bali and NTT is acceptable.

\section{CONCLUSION}

The conclusions of this study are as follows:

1. The ratio of CAR, NPL and LDR significantly affects credit growth in Regional Development Banks in Java, Bali and NTT through simultaneous testing with P value of F or a significance level of $0.004<a$ '(5\%)

\footnotetext{
The Effect Of CAR, NPL \& LDR On The Profit Improvement Of Regional Development Bank In Indonesia By Using Credit Growth As Intervening Variable (Research on Regional Development Banks in Java, Bali \& NTT) Period $2011-2015$
}

Ririn Poerwanti, Titis Puspitaningrum Dewi Kartika 
2. The financial ratios assessed from the CAR, NPL and LDR before involving intervening variables of credit growth significantly affected the increase in profit at Regional Development Banks in Java, Bali and NTT as evidenced by simultaneous test results with P-value of F or significance of $0.019<\mathrm{a}$ '(5\%)

3. The financial ratios of CAR, NPL and LDR by involving intervening variable of credit growth significantly affect the profit improvement in Regional Development Banks in Java, Bali and NTT is proven through simultaneous test results with P-value value of $\mathrm{F}$ or significance level of $0.000<\mathrm{a}$ ' $(5 \%)$

4. The capital adequacy ratio (CAR) negatively and significantly affects credit growth in Regional Development Banks in Java, Bali and NTT with regression coefficient of -0.856 and significance level of 0.019 ( $\mathrm{p}<0.05$ ) have a positive and significant effect on the increase profit in Regional Development Banks in the islands of Java, Bali and NTT with regression coefficient value of 0.227 with a significance level of 0.025 ( $p<0.05)$.

5. The ratio of non-performing loans (NPLs) has a negative and significant effect on the increase of profit in Regional Development Banks in Java, Bali and NTT with regression coefficient of 0.513 and significance level of 0.002 ( $\mathrm{p}<0.005)$.

6. The ratio of lending rate (LDR) positively and significantly influenced the increase of profit of Regional Development Bank in Java, Bali and NTT with regression coefficient value of 0.131 and significance level of 0.017 ( $\mathrm{p}<0.05)$.

7. Credit growth can mediate positively and significantly affect the ratio of CAR, NPL and LDR to increase profit in Regional Development Banks in Java, Bali and NTT with regression coefficient value of 0.113 and significance level of $0.07(\mathrm{p}<0.05)$

Some suggestions that can be given from this research include:

1. For management, it is better to pay more attention to LDR ratio to stay in the position of $80 \%-110 \%$ in order to maintain the optimization of credit without any suspension, but if the ratio is above $110 \%$, then it should not meet the demand for credit because it is feared that there will be a suspension, so it can be concluded that the higher the LDR value, the liquidity of the banking is very risky. Otherwise, the lower the LDR ratio, the effectiveness of bank lending will be very low.

2. The effectiveness of lending is one of the efforts in increasing the company profit, so the role of bank as the intermediation of funds can work properly.

3. In the provision of credit, banks should be more careful in analyzing the ability of debtors in fulfilling their obligations in paying installments. The bank shall conduct assessing, reviewing and binding of the collateral to minimize the risk incurred.

\section{REFERENCES}

Aini (2006), Analisis Pengaruh CAR, LDR, ROA, dan Besaran Perusahaan trhadap Perubahan Laba Perusahaan perbankan yang Terdaftar di BEJ

\footnotetext{
The Effect Of CAR, NPL \& LDR On The Profit Improvement Of Regional Development Bank In Indonesia By Using Credit Growth As Intervening Variable (Research on Regional Development Banks in Java, Bali \& NTT) Period $2011-2015$
}

Ririn Poerwanti, Titis Puspitaningrum Dewi Kartika 
Dendawijaya, Lukman. 2009. Manajemen Perbankan Edisi Kedua. Ghalia Indonesia : Jakarta

Dwi Lestari, 2011, Rasio Keuangan Bank Terhadap Peningkatan Laba Bank Devisa yang Terdaftar di Bursa Efek.

Eddy Herjanto 2012, "Faktor-Faktor yang berpengaruh Terhadap Profitabilitas Bank".

Hesti Werdaningtyas, 2002 "Faktor yang Mempengaruhi Profitabilitas Bank Take Over Pramerger di Indonesia, Jurnal Manajemen Indonesia. Vol 1, no. 2, pp. 24 - 39.

Ida Bagus \& Putu K, 2018. “The Influence of Internal \& External Factors With Risk Factors as Mediation Variables to Financial Performance of Regional Development Bank in Indonesia".

Kumbirai, 2010. "Afinancial Ratio Analysis of Commercial Bank Performance in South Africa, Journal for Economics and Finance".

Muhammad Sarifudin, 2005. "Faktor-faktor yang Mempengaruhi Laba pada Perusahaan Perbankan yang Listed di BEJ Periode 2000 s/d 2002".

Noni Nuraini, 2016. " Pengaruh Perubahan ROA, BOPO, NPM \& LDR Terhadap Perubahan Laba".

Pelo, 2012.”Faktor-faktor yang berpengaruh Terhadap Profitabitas Bank yang Terdapat di Bursa Efek”.

Prastiono,2009. Analisis Pengaruh CAR, NPL, BOPO, NIM dan LDR Terhadap Pertumbuhan Laba Pada Bak Umum Di BEI Tahun 2004-2007. Pustaka Univ. Diponegoro. Dipublikasikan

Rahman, Teddy (2009), Analisisi Pengaruh CAR, BOPO, NPL, NIM dan LDR Terhadap Perubahan Laba.

Prayudi, Arditya. 2011 Pengaruh Capital Adequacy Ratio (CAR, Non Performing Loan (NPL), BOPO, Return On Asset (ROA) dan Net Interest Margin (NIM) Terhadap Loan to Deposit Ratio (LDR). Tesis Program. Studi Magister Manajement Program Pascasarjana Universitas Diponegoro, Dipublikasikan

Yunianingsih, Yeni (2011). Analisis CAR, BOPO, NPL, NIM dan LDR Terhadap Pertumbuhan Kredit dan Implikasinya Pada Pertumbuhan Laba Bank : Suatu Penelitian Pada Periode 2001 - 2010 : Jakarta

Yuliani, 2007, Hubungan Efisiensi Operasional dengan Kinerja Profitabiltas pada Sector Perbankan yang Go

Public di Bursa Efek

Link Website: www.bi.go.id

Riyadi, Slamet. 2006. Banking Assets And Liability Management. Jakarta: Lembaga Penerbit Fakultas Ekonomi Universitas Indonesia

Rini DH, 2016. “The Influence of The Bank's Performance Ratio to Profit Growth on Banking Companies in Indonesia".

Renaldy Syahputra, Andreas \& Errin (2014). "Pengaruh Rasio Keuangan Terhadap Pertumbuhan Laba Bank Pembangunan Daerah di Indonesia dengan Pertumbuhan Kredit sebagai Variabel Intervening”.

Santoso, Singgih. 2010. Statistik Multivariat. Jakarta : PT Elex Media Komputindo

Sianturi, 2012. "Pengaruh Rasio Keuangan ( CAR, LDR, NPL, BOPO \& NIM) Terhadap ROA".

Sustari Alamsyah 2015, “Pengaruh CAR, NPL, LDR, ROA \& NIM Terhadap Pertumbuhan Laba”.

Wisnu Mawardi, 2005. Analisis Faktor-faktor yang Mempengaruhi Kinerja Keuangan Bank Umum di Indonesia. Jurnal Bisnis Strategi. Vol. 14. No. 1, Juli 2005.

\footnotetext{
The Effect Of CAR, NPL \& LDR On The Profit Improvement Of Regional Development Bank In Indonesia By Using Credit Growth As Intervening Variable (Research on Regional Development Banks in Java, Bali \& NTT) Period $2011-2015$
}

Ririn Poerwanti, Titis Puspitaningrum Dewi Kartika 
